\title{
Evaluasi Kinerja Pembangunan Bidang Pendidikan di Kabupaten Ngawi Tahun 2016-2018, Provinsi Jawa Timur
}

\author{
Fajar Sidik*, Firmansyah \\ Fakultas Ilmu Pendidikan, Universitas Negeri Yogyakarta \\ *Corresponding Author. e-mail: fajarsidik@uny.ac.id
}

\begin{abstract}
Abstrak
Problem kemiskinan dihadapi daerah-daerah telah menyebabkan perekonomian daerah kurang berkembang, termasuk daerah Ngawi, provinsi Jawa Timur. Tiga tahun terakhir (Tahun 2016-2018), pemerintah daerah kabupaten Ngawi berhasil menurunkan angka kemiskinan. Meski berhasil menurunkan angka kemiskinan, Ngawi masih dikategorikan sebagai daerah miskin dibanding dengan daerah-daerah yang ada di Provinsi Jawa Timur. Kondisi ini menunjukkan bahwa kinerja pemerintah daerah Kabupaten Ngawi dalam menjalankan program pengentasan kemiskinan perlu dievaluasi. Melalui dimensi pendidikan, kinerja pemerintah daerah Kabupaten Ngawi dicermati untuk menemukan akar persoalan yang dialami penduduk miskin. Penelitian kepustakaan digunakan untuk menilai kinerja pemerintah daerah di bidang pendidikan dari tahun 2016 hingga tahun 2018. Berdasarkan analisis data yang dilakukan, hasil penelitian ini menunjukkan bahwa kinerja pemerintah daerah kabupaten Ngawi dari tahun 2016-2018 belum mampu mencapai target yang direncanakan.
\end{abstract}

Kata kunci: perekonomian daerah, kemiskinan, pendidikan

\begin{abstract}
The problem of poverty faced by regions has caused regional economies to be underdeveloped, including the Ngawi region, East Java province. In the last three years (in 2016-2018), the local government of Ngawi has succeeded in reducing poverty. Although it succeeded in reducing poverty, Ngawi is still categorized as a poor area compared to the regions in East Java Province. This condition shows that the performance of the Ngawi Regency government in carrying out poverty alleviation programs needs to be evaluated. Through the education dimension, the performance of the local government of Ngawi Regency is examined to find the root causes of the problems experienced by the poor. The library research is used to assess the performance of local government in education from 2016 to 2018. Based on data analysis conducted, the results of this study indicate that the performance of the Ngawi district government from 2016-2018 has not been able to achieve the planned targets.
\end{abstract}

Keywords: regional economy, poverty, education

How to Cite: Sidik, F., \& Firmansyah. (2020). Evaluasi Kinerja Pembangunan Bidang Pendidikan di Kabupaten Ngawi Tahun 2016-2018, Provinsi Jawa Timur. FOUNDASIA, 11(1), 24-34. 


\section{PENDAHULUAN}

Kualitas sumber daya manusia menjadi faktor penentu dalam kemajuan suatu daerah. Daerah dengan perekonomian yang maju biasanya ditopang dengan kualitas sumber daya manusia yang memadai atau begitu juga berlaku sebaliknya. Sumber daya manusia ditentukan oleh sejauhmana kualitas penyelenggaraan pendidikan yang dijalankan oleh pemerintah daerah kepada masyarakat (Hafidh, 2011). Dengan pelayanan pendidikan berkualitas yang diberikan kepada masyarakat oleh pemerintah daerah, maka kualitas sumber daya manusia akan mampu ditingkatkan untuk mendorong percepatan pembangunan-pertumbuhan perekonomian suatu daerah dan kesinambungannya (Nugroho, 2016).

Kualitas sumber daya manusia dapat dicermati melalui sejauhmana kinerja pemerintah daerah dalan penyelenggaraan pendidikan kepada masyarakatnya. Salah satunya indikator yang dapat digunakan sebagai acuan adalah capaian Indeks Pembangunan Manusia (IPM) di sektor pendidikan. IPM digunakan untuk menjelaskan bagaimana penduduk dapat mengakses hasil pembangunan dalam memperoleh pendidikan. Sebab, IPM menjadi indikator penting untuk mengukur keberhasilan suatu wilayah dalam upaya membangun kualitas hidup manusia (masyarakat/penduduk). IPM juga dapat digunakan untuk menentukan peringkat atau level pembangunan daerah. Bagi Indonesia, IPM merupakan data strategis karena selain sebagai ukuran kinerja Pemerintah Daerah, IPM juga digunakan sebagai salah satu alokator dalam penentuan Dana Alokasi Umum (DAU) (BPS, 2020). Sumber dana dan penentuan DAU dan Dana Alokasi Khusus Bidang Pendidikan menentukan kualitas pembangunan daerah di sektor pendidikan (Lugastoro \& Ananda, 2013). Di Kabupaten Ngawi, capaian IPM yang diperoleh menunjukkan di bawah capaian rata-rata tingkat Provinsi maupun Nasional (Suara Indonesia, 2020).

Capaian IPM sektor pendidikan yang belum optimal di atas berkaitan dengan persoalan kemiskinan yang belum optimal ditangani Pemerintah Kabupaten Ngawi (Mirza, 2012; Novita Dewi dkk., 2017). Sebab, semakin tinggit ingkat pendidikan seseorang maka semakin tinggi IPM suatu daerah (Maulana \& Bowo, 2013). Secara nasional, Badan Pusat Statistik melaporkan jumlah penduduk miskin di Indonesia pada Maret 2019 berjumlah 25,14 juta jiwa atau 9,41 persen. Angka ini lebih rendah 0,53 juta jiwa dibandingkan dengan penduduk berpengeluaran per kapita di bawah garis kemiskinan pada September 2018. Dalam laporan, BPS merinci peta sebaran kemiskinan di Indonesia dan menunjukkan tiga provinsi memiliki penduduk miskin lebih banyak dibanding provinsi lainnya, yaitu Jawa Timur dengan 4,11 juta jiwa penduduk miskin, Jawa Tengah dengan 3,74 juta jiwa, dan Jawa Barat dengan 3,4 juta jiwa (Kompas, 2019). Spesifik, kasus di Kabupaten Ngawi salah satu wilayah Provinsi Jawa Timur, tingkat kemiskinan wilayah dalam tiga tahun terakhir (tahun 2015 hingga 2018) tercatat menurun, yaitu 15,61 pada tahun 2015 menjadi 14,83 pada tahun 2018 (Badan Pusat Statistik Kabupaten Ngawi, 2020). Namun, angka kemiskinan wilayah Kabupaten Ngawi berada di atas rata-rata kemiskinan nasional dan masih tergolong tinggi. Dinas Sosial setempat telah mencatat sebanyak 142.005 keluarga dengan total 431.174 jiwa masuk kategori miskin. Prosentase kemiskinan di wilayah Ngawi yang tercatat sebesar $45 \%$ dari total populasi penduduk tersebar merata di 19 kecamatan yang ada (Jawa Pos, 2019). Situasi dan kondisi ini menempatkan Kabupaten Ngawi berada pada posisi 10 besar sebagai daerah termiskin di Provinsi Jawa Tengah (Radar Madiun, 2020).

Persoalan kemiskinan yang terjadi di Kabupaten Ngawi dapat dicermati dari dimensi pendidikan. Kemiskinan adalah persoalan kompleks yang dipengaruhi oleh berbagai faktor yang saling berkaitan antara lain pendapatan, kesehatan, pendidikan, akses terhadap barang dan jasa, lokasi geografis, gender dan kondisi lingkungan (Ustama, 2009). Namun, kemiskinan selama ini lebih sering dikaitkan dengan dimensi ekonomi karena dimensi inilah yang paling mudah diamati, diukur, dan dibandingkan (Suryawati, 2005). Chambers menjelaskan dimensi kemiskinan bersifat multidimensional sebagai suatu konsep yang utuh, yakni: (1) kemiskinan (proper), (2) ketidakberdayaan (powerless), (3) kerentanan menghadapi situasi darurat (state of emergency), (4) ketergantungan (dependency), dan (5) keterasingan (isolation). Kemiskinan sebagai suatu situasikondisi deprivasi (kekurangan atau keterampasan) mulai dari pendapatan, kekuatan sosial (keadilan atau persamaan hak), ketidaksiapan menghadapi situasi dan kondisi darurat (bencana alam, biaya 
pengobatan untuk kesehatan), ketergantungan yang tinggi dari pihak lain, keterasingan dari pusatpusat pertumbuhan ekonomi (Sumargo \& Simanjuntak, 2019).

Secara konseptual, definisi mengenai kemiskinan sangat beragam dan tergantung dari permasalahan yang ingin didiskusikan. Kemiskinan apabila dipandang secara kuantitatif dan materialistik, kemiskinan dimaknai sebagai "kondisi ketidakmampuan untuk meraih standard hidup minimal". Standard pengukuran yang digunakan dalam hal ini untuk menilai standard hidup, termasuk barang-barang rumah tangga dan pengeluaran per kepala dan juga dimensi kesejahteraan lain, seperti kesehatan, gizi, harapan hidup, kematian balita, keaksaraan dan tingkat pendaftar disekolah serta akses pada barang-barang umum atau sumber kekayaan umum. Kemudian, kemiskinan bukan hanya sekedar masalah kesenjangan pendapatan (income discrepancy), tetapi lebih kompleks lagi bahwa kemiskinan menyangkut ketidakberdayaan (incapability), ketiadaan pengetahuan dan keterampilan (lack ff knowledge and skills) dan kelangkaan akses pada modal dan sumber daya (scarcity of capital and resource) (Ustama, 2009: 3).

Kemudian, berdasarkan bentuk-tipologinya, menurut Nasikun menjelaskan kemiskinan dibedakan menjadi empat, yaitu kemiskinan absolut, relatif, kultral, dan struktural. Yang dimaksud dengan kemiskinan absolut, yaitu bila pendapatannya di bawah garis kemiskinan atau tidak cukup untuk memenuhi pangan, sandang, kesehatan, perumahan, dan pendidikan yang diperlukan untuk bisa hidup dan bekerja. Kemiskinan relatif, yaitu kondisi miskin karena pengaruh kebijakan pembangunan yang belum menjangkau seluruh masyarakat, menyebabkan ketimpangan pendapatan. Kemiskinan kultural, yaitu mengacu pada persoalan sikap seseorang atau masyarakat yang disebabkan oleh faktor budaya, seperti tidak mau berusaha memperbaiki tingkat kehidupan, malas, pemboros, tidak kreatif meskipun ada bantuan dari pihak luar. Kemiskinan struktural, yaitu situasi miskin yang disebabkan karena rendahnya akses terhadap sumber daya yang terjadi dalam suatu sistem sosial budaya dan sosial politik yang tidak mendukung pembebasan kemiskinan, tetapi seringkali menyebabkan suburnya kemiskinan itu sendiri (Suryawati, 2005).

Melalui dimensi pendidikan, persoalan kemiskinan dapat dipahami bahwa penduduk miskin mengalami ketidakberdayaan, keterasingan, dan kekuarangan karena ketidakmampuan untuk mendapatkan/mengakses pendidikan yang berkaulitas bagi dirinya. Sementara, berdasar UUD 1945 dan UU Nomor 20 tahun 2003 tentang Sistem Pendidikan Nasional, penduduk miskin dijamin untuk mendapatkan hak pendidikan yang berkualitas. Peran pemerintah daerah mengurangi angka kemiskinan tertuang dalam Pasal 53A (1, Peraturan Pemerintah (PP) Nomor 66 Tahun 2010 tentang Pengelolaan dan Penyelenggaraan) Pendidikan. Dalam ketentuan ini menyebutkan satuan pendidikan menengah dan satuan pendidikan tinggi yang diselenggarakan pemerintah daerah, sesuai dengan kewenangan masing-masing wajib mengalokasikan tempat bagi para calon peserta didik berkewarganegaraan Indonesia, yang memiliki potensi akademik memadai dan kurang mampu secara ekonomi, paling sedikit 20 persen dari jumlah keseluruhan peserta didik baru.

Situasi dan kondisi ini menunjukkan bahwa sejauhmana kinerja pembangunan daerah Kabupaten Ngawi merealisasikan program-program yang dijalankan di sektor pendidikan. Pertanyaan yang diajukan dalam tulisan ini, yaitu; bagaimana kharakteristik penduduk daerah Kabupaten Ngawi apabila dilihat dari tingkat pendidikan?, bagaimana distribusi kemiskinan penduduknya?, apa dampak kemiskinan yang dihadapi penduduk terhadap akses pendidikan yang diperoleh?, dan bagaimana hasil capaian kinerja pemerintah daerah di sektor pendidikan dan tindakan apa yang perlu dilakukan pemerintah daerah setempat?

Tulisan ini bertujuan menjelaskan (1) kharaktersiktik mata pencaharian penduduk di daerah Kabupaten Ngawi dan tingkat pendidikan yang ditamatkan, (2) distribusi kemiskinan dilihat dari ketegori kesejahteraan penduduknya, (3) hasil capaian IPM di sektor pendidikan, dan (4) menampilkan hasil capaian kinerja pemerintah daerah kabupaten Ngawi di sektor pendidikan. Kontribusi penelitian ini, yaitu memberikan bahan pengambilan kebijakan sektor pendidikan kepada pemerintah daerah Kabupaten Ngawi. Dengan demikian, hasil penelitian ini diharapkan membantu dalam memberikan masukan terhadap program-program pendidikan yang dijalankan terhadap arah persoalan yang akan diintervensi untuk segera diselesaikan. 


\section{METODE PENELITIAN}

Sesuai dengan persoalan yang akan dicermati di atas, penelitian ini menggunakan studi kepustakaan. Studi kepustakaan relevan digunakan mempertimbangkan bahwa persoalan dan rumusan masalah yang diajukan lebih memadai lewat penelitian pustaka dan sebaliknya kurang memungkinkan datanya apablika menggunakan dari riset lapangan (Zed, 2004). Pendekatan penjelasan hasil studi kepusatakaan dilakukan secara kualitatif dan kuantitatif. Penjelasan kuantitatif digunakan untuk memaparkan kuantifikasi sederhana melalui trend capaian hasil yang diwujudkan dalam bentuk angka/prosesntase. Sedangkan, penjelasan kualitatif digunakan untuk memberikan penjelasan hasil analisis data yang diperoleh dari hasil kuantifikasi maupun intepretasi hasil analisis data. Sumber data yang digunakan dalam studi kepustakaan umumnya berupa data sekunder, seperti buku, jurnal, hasil laporan, artikel dan lain-lain (Zed, 2004). Data sekunder yang digunakan dalam penelitian ini, antara lain: Kabupaten Ngawi Dalam Angka 2016-2019, Statistik Daerah Kabupaten Ngawi 2017-2019, Statistik Kesejahteraan Rakyat Ngawi 2016-2018, Indikator Kesejahteraan Rakyat Kabupaten Ngawi dari tahun 2016-2018, dan RPJMD Kabupaten Ngawi 2005-2025. Dalam mekanisme penilaian (evaluasi) capaian kinerja daerah, penelitian ini menilai IPM dari sektor pendidikan. Indikator yang dijadikan sebagai penilaian, antara lain; (1) Persentase penduduk di bawah garis kemiskinan, (2) Angka melek huruf, (3) Angka rata-rata lama sekolah, (4) Angka Putus Sekolah (APS) SD/MI, (5) Angka Putus Sekolah SMP/Mts, dan (6) Angka Putus Sekolah SMA/SMK. Evaluasi capaian kinerja pemerintah daerah Kabupaten Ngawi dengan cara membandingkan target capaian sektor pendidikan yang tertuang dalam RPJMD tahun 2015-2019 dengan hasil realisasi yang dicapai dari tahun 2016-2018. Data sekunder ini kemudian dilakukan analisis melalui tiga tahap meliputi; (1) data sekunder dikumpulkan dan diseleksi sesuai fokus masalah yang diteliti, (2) data yang berhasil diseleksi kemudian diorganisasikan dan ditampilkan, dan (3) data yang berhasil ditampilkan kemudian dianalisis untuk disimpulkan (Huberman \& Miles, 2002). Hasil analisis data dan penjelasan yang diperoleh disajikan dalam bagian hasil dan pembahasan di bawah ini.

\section{HASIL DAN PEMBAHASAN}

Pada bagian hasil dan pembahasan ini menjelaskan empat bagian sesuai dengan rumusan penelitian yang telah diajukan di awal, antara lain; (1) kharaktersiktik mata pencaharian penduduk di daerah Kabupaten Ngawi dan tingkat pendidikan yang ditamatkan, (2) kondisi kemiskinan dilihat dari ketegori kesejahteraan penduduknya, (3) hasil capaian IPM di sektor pendidikan, dan (4) menampilkan hasil capaian kinerja pemerintah daerah kabupaten Ngawi di sektor pendidikan.

\section{Kharakteristik Penduduk di Kabupaten Ngawi}

Kabupaten Ngawi terletak di wilayah barat Propinsi Jawa Timur yang berbatasan langsung dengan Propinsi Jawa Tengah. Berdasarkan posisi geografisnya,Kabupaten Ngawi memiliki batasbatas: Utara - Kabupaten Grobogan, Kabupaten Blora (Provinsi Jawa Tengah) dan Kabupaten Bojonegoro; Selatan - Kabupaten Madiun dan Kabupaten Magetan; Barat - Kabupaten Karanganyar dan Kabupaten Sragen (Provinsi Jawa Tengah); Timur - Kabupaten Madiun. Luas wilayah Kabupaten Ngawi adalah 1.295,98 Km2, sebagian besar sekitar 39\% atau sekitar 504,8 km² berupa lahan sawah (pertanian), sehingga perekonomian Kabupaten Ngawi masih didominasi sektor pertanian. Tahun 2018, sebagian besar penduduknya berusia 15 tahun ke atas bekerja pada sektor pertanian, perhutanan, perburuan, dan perikanan sebanyak 252403 yang terdiri laki-laki (144.923) dan perempuan (107.480) (BPS Kab Ngawi, 2019).

Kabupaten Ngawi terbagi dalam 19 Kecamatan dan memiliki 217 Desa. Tercatat pada akhir tahun 2018, wilayah luas Wilayah masing-masing Kecamatan, yaitu: Sine (80,22 Km2), Ngrambe $(57,49 \mathrm{Km} 2)$, Jogorogo $(65,84 \mathrm{Km} 2)$, Kendal $(84,56 \mathrm{Km} 2)$, Geneng $(52,52 \mathrm{Km} 2)$, Gerih $(34,52$ $\mathrm{Km} 2)$, Kwadungan (30,30 Km2), Pangkur (29,41 Km2), Karangjati (66,67 Km2), Bringin (62,62 Km2), Padas (50,22 Km2), Kasreman (31,49 Km2), Ngawi (70,56 Km2), Paron (101,14 Km2), Kedunggalar (129,65 Km2), Pitu (56,01 Km2), Widodaren (92,26 Km2), Mantingan (62,21 Km2) dan Karanganyar (138,29 Km2). Topografi wilayah Kabupaten Ngawi berupa dataran tinggi dan 
tanah datar. Tercatat 4 Kecamatan terletak pada dataran tinggi yaitu Sine, Ngrambe, Jogorogo dan Kendal yang terletak di kaki Gunung Lawu. Lima belas Kecamatan sisanya berupa tanah datar. Kecamatan Karanganyar dan Kecamatan Kedunggalar merupakan Kecamatan yang memiliki wilayah paling luas yaitu sebesar $138,29 \mathrm{Km} 2$ atau 10,67 persen dan $129,65 \mathrm{Km} 2$ atau 10,00 persen (BPS Kab Ngawi, 2019).

Pada tahun 2018, berdasarkan lapangan pekerjaan utama, penduduk penduduk yang bekerja di sektor, yaitu Pertanian, Kehutanan, Perburuan, dan Perikanan (252403 orang), Pertambangan dan Penggalian (7370 orang ), Industri Pengolahan (37669 orang), Listrik, Gas, dan Air (857 orang), Bangunan (31943 orang), Perdagangan Besar, Eceran, Rumah Makan, dan Hotel (88190 orang), Angkutan, Pergudangan, dan Komunikasi (7383 orang), Keuangan, Asuransi, Usaha Persewaan Bangunan, Tanah, dan Jasa Perusahaan (10192 orang), Jasa Kemasyarakatan, Sosial, dan Perorang (43982 orang) (BPS, 2019). Persentase penduduk berdasarkan lapangan pekerjaan utama penduduk di Kabupaten Ngawi pada tahun 2018 dapat di lihat pada diagaram di bawah ini.

Berdasarkan tingkat pendidikan tertinggi yang ditamatkan, Jumlah Penduduk Berumur 15 Tahun Ke Atas yang Termasuk Angkatan Kerja Menurut Pendidikan Tertinggi yang Ditamatkan (Jiwa) di Kabupaten Ngawi tahun 2018 dapat dilihat pada diagaram di bawah. Jumlah tenaga kerja menunjukkan didominasi tamatan Sekolah Dasar (265287 orang), Sekolah Menengah Pertama (98601 orang), Sekolah Menengah Atas (44261 orang), Sekolah Menengah Kejuruan (60111 orang), Diploma I/II/III/ Akademi (4210 orang), Universitas (26634 orang).

\section{Distribusi Kemiskinan Wilayah di Kabupaten Ngawi}

BPS Provinsi Jawa Timur tahun 2018, posisi tingkat jumlah kemiskinan penduduk Kabupaten Ngawi dibandingan dengan kabupaten lain menunjukkan bahwa tingkat kemiskinan Kabupaten Ngawi masih dikatakan tinggi di Provinsi Jawa Timur (BPS Provinsi Jawa Timur, 2019). Kabupaten Ngawi memiliki jumlah penduduk miskin sebanyak 123.090 Jiwa $(14,83 \%)$ di atas rerata jumlah penduduk miskin di Provinsi Jawa Timur, yakni 10,98\%. Pada tahun 2016, jumlah penduduk di wilayah Kabupaten Ngawi sebesar 895.895 jiwa dengan jumlah penduduk miskin sebesar 126.660 jiwa. Pada tahun 2017, jumlah penduduk mengalami peningkatan menjadi 908.268 jiwa dari tahun sebelumnya sebesar 895.895 jiwa, namun jumlah penduduk miskin mengalami penurunan dari, yaitu dari 126.660 jiwa menjadi 123.760 jiwa dari tahun sebelumnya. Pada tahun 2018, jumlah penduduk mengalami penurunan menjadi 908.016 jiwa disertai dengan penurunan jumlah penduduk miskin menjadi 123.090 jiwa dari tahun sebelumnya. Berdasarkan analisis data ini, pertumbuhan prosentase jumlah penduduk miskin di wilayah Kabupaten Ngawi menunjukkan terjadi penurunan dalam tiga tahun terakhir, yaitu 15,27\% (tahun 2016) menjadi 14,91\% (tahun 2017) dan turun lagi menjadi 14,83\% (tahun 2018). Dari 19 Kecamatan yang ada di Kabupaten Ngawi, lima wilayah yang memiliki jumlah penduduk miskin (kantong) terbanyak pada tahun 2016, antara lain: Kecamatan Paron (29.977 Jiwa), Kecamatan Ngawi (24.953 Jiwa), Kecamatan Kedunggalar (74.523 Jiwa), Widodaren (21.040 Jiwa), dan Karangjati (49.313 Jiwa).

Berdasarkan tingat kesejahteraan keluarga yang tersebar di 19 kecamatan, tingkatkan kesejahteraan keluarga miskin dikelompokkan menjadi 5 (lima) tahapan menurut BKKBN, antara lain:

a. Tahapan Keluarga Pra Sejahtera (KPS), yaitu keluarga yang tidak memenuhi salah satu dari 6 (enam) indikator Keluarga Sejahtera I (KS I) atau indikator "kebutuhan dasar keluarga" (basic needs).

b. Tahapan Keluarga Sejahtera I (KSI), yaitu keluarga mampu memenuhi 6 (enam) indikator tahapan KS I, tetapi tidak memenuhi salah satu dari 8 (delapan) indikator Keluarga Sejahtera II atau indikator "kebutuhan psikologis" (psychological needs) keluarga.

c. Tahapan Keluarga Sejahtera II, yaitu keluarga yang mampu memenuhi 6 (enam) indikator tahapan KS I dan 8 (delapan) indikator KS II, tetapi tidak memenuhi salah satu dari 5 (lima) indikator Keluarga Sejahtera III (KS III), atau indikator "kebutuhan pengembangan" (develomental needs) dari keluarga.

d. Tahapan Keluarga Sejahtera III, yaitu keluarga yang mampu memenuhi 6 (enam) indikator tahapan KS I, 8 (delapan) indikator KS II, dan 5 (lima) indikator KS III, tetapi tidak memenuhi 
salah satu dari 2 (dua) indikator Keluarga Sejahtera III Plus (KS III Plus) atau indikator "aktualisasi diri" (self esteem) keluarga.

e. Tahapan Keluarga Sejahtera III Plus, yaitu keluarga yang mampu memenuhi keseluruhan dari 6 (enam) indikator tahapan KS I, 8 (delapan) indikator KS II, 5 (lima) indikator KS III, serta 2 (dua) indikator tahapan KS III Plus. Berdasarkan klasifikasi tingkat kesejahteraan keluarga ini, persebaran penduduk miskin pada tahun 2016 dapat dicermati pada data tabel di bawah.

Tabel 1. Persebaran Tingkat Kesejahteraan Keluarga di Kabupaten Ngawi Tahun 2016

\begin{tabular}{lcccccr}
\hline \multirow{2}{*}{ Kecamatan } & Pra Sejahtera & \multicolumn{4}{c}{ Keluarga Sejahtera } & \multirow{2}{*}{ Total } \\
\cline { 3 - 6 } Sine & 6333 & 1073 & 1296 & 4189 & 33 & 12924 \\
\hline Ngrambe & 7760 & 2311 & 1910 & 1755 & 29 & 13765 \\
\hline Jogorogo & 7580 & 310 & 499 & 5603 & 7 & 13999 \\
\hline Kendal & 2156 & 5465 & 5326 & 3198 & 14 & 16159 \\
\hline Geneng & 2638 & 2338 & 4639 & 7601 & 461 & 17677 \\
\hline Gerih & 2547 & 2259 & 3204 & 3526 & 35 & 11571 \\
\hline Kwadungan & 2884 & 730 & 804 & 5454 & - & 9872 \\
\hline Pangkur & 8730 & 77 & 106 & 2265 & 14 & 11192 \\
\hline Karangjati & 16952 & 248 & 314 & 2009 & - & 19523 \\
\hline Bringin & 9389 & 942 & 636 & 577 & - & 11544 \\
\hline Padas & 9965 & 714 & 545 & 462 & - & 11686 \\
\hline Kasreman & 6276 & 924 & 488 & 302 & - & 7990 \\
\hline Ngawi & 9005 & 2545 & 4069 & 8911 & 423 & 24953 \\
\hline Paron & 11748 & 6000 & 5405 & 6447 & 377 & 29977 \\
\hline Kedunggalar & 13549 & 1571 & 1830 & 6191 & 108 & 23249 \\
\hline Pitu & 6353 & 31 & 56 & 3335 & - & 9775 \\
\hline Widodaren & 14920 & 679 & 1299 & 4037 & 105 & 21040 \\
\hline Mantingan & 5462 & 3247 & 2375 & 1321 & 10 & 12415 \\
\hline Karanganyar & 7006 & 537 & 552 & 1908 & 29 & 10026 \\
\hline Kab. Ngawi & $\mathbf{1 5 1 2 5 3}$ & $\mathbf{3 2 0 0 1}$ & $\mathbf{3 5 3 5 3}$ & $\mathbf{6 9 0 9 1}$ & $\mathbf{1 6 4 5}$ & $\mathbf{2 8 9 3 3 7}$ \\
\hline
\end{tabular}

Sumber: BPS Kabupaten Ngawi Dalam Angka 2018.

\section{Hasil Capaian IPM Sektor Pendidikan di Kabupaten Ngawi}

Indikator kemiskinan multidimensional dalam IPM dapat dimanfaatkan sebagai dasar mengidentifikasi dan mengukur aspek-aspek sektor pendidikan yang dipengaruhi persoalan kemiskinan. Kakwani dan Silber menjelaskan bahwa pergeseran penelitian tentang kemiskinan telah terjadi: dari pengukuran yang sifatnya unidimensi menjadi multidimensi dengan mengarah pada empat pokok dasar kemiskinan multidimensional: mulai dari terbatasnya peluang (chance) ekonomi, berketerampilan rendah, ketidakpastian hidup berkelanjutan, dan ketidakberdayaan. Situasi dan kondisi kemiskinan dipengaruhi dari beberapa dimensi yang berbeda, salah satunya pendidikan. Kemiskinan menunjukkan kondisi penduduk dalam kondisi yang mencerminkan kegagalan seseorang unutk mendapatkan akses dan kualitas pendidikan (Sumargo \& Simanjuntak, 2019: 161).

Pembangunan untuk mencapai kesejahteraan masyarakat tidak hanya dipandang dari aspek ekonomi saja, tetapi juga dari aspek sosial lainnya, salah satunya adalah aspek pendidikan. Indikator di sektor/bidang pendidikan dapat digunakan terutama oleh pembuat kebijakan untuk mengidentifikasi tantangan ke depan dan sebagai bahan evaluasi dalam rangka mencapai kesejahteraan rakyat. Semakin tinggi jenjang pendidikan ditamatkan oleh penduduk suatu daerah secara tidak langsung dapat menunjukkan tingkat kemajuan daerah di Kabupaten Ngawi (Indikator Kesejahteraan Rakyat Kabupaten Ngawi 2017/2018). Berikut perkembangan sektor pendidikan di Kabupaten Ngawi dari tahun 2016-2018. 
a. Tahun 2016

Berdasarkan jumlah penduduk 15 tahun ke atas menurut ijazah yang dimiliki tahun 2016, mayoritas penduduk Ngawi masih berijazah SD/MI sederajat. Tercatat 42 persen penduduk Ngawi hanya berijazah SD sederajat. Terbanyak kedua, penduduk berijazah SMA sederajat yaitu sebesar 17,02 persen. Separuh lebih penduduk Ngawi berpendidikan rendah yaitu SD sederajat atau tidak berijazah sebesar 64,61 persen. Sementara itu, angka buta huruf menunjukkan persentase penduduk 10 tahun ke atas yang tidak bisa membaca dan menulis di Ngawi terdapat sekitar 11,8 persen, dari 11, 81 persen penduduk 15 tahun keatas yang masih buta huruf sebagian besar berjenis kelamin permepuan yaitu sebesar 15,62 persen dan 7,80 persen laki-laki (Statistik Daerah Kabupaten Ngawi 2017). Bila dirinci berdasarkan gender/jenis kelamin, kemampuan baca antara perempuan jumlahnya menunjukkan dua kali lipat dibanding dengan laki-laki, yaitu 15,62 persen dibanding 7,80 persen (Indikator Kesejahteraan Rakyat Kabupaten Ngawi 2016).

Pada tahun 2016, nilai APM untuk jenjang SD/MI mengalami kenaikan sebanyak 1,89 point dibandingkan tahun 2015. Sedangkan untuk jenjang SMP/MTs dan SMA/SMK, nilai APM mengalami penurunan sekitar 6 point untuk SD/MI dan turun 6,03 point untuk SMP/MTs serta turun 11,12 point untuk SMA/MA. Nilai APM dan APK yang menurun pada jenjang pendidikan yang lebih tinggi menunjukkan berkurangnya jumlah anak yang melanjutkan sekolah. Situasi dan kondisi berkurangnya jumlah anak yang melanjutkan sekolah, antara lain faktor (ketersediaan biaya, minat), sulitnya akses ke perguruan tinggi. Rata-rata lama sekolah penduduk Kabupaten Ngawi hanya mencapai 6,54 tahun (Statistik Daerah Kabupaten Ngawi 2017).

Angka putus sekolah (APTS) merupakan perbandingan antara anak-anak yang sudah tidak bersekolah lagi atau yang tidak menamatkan suatu jenjang pendidikan tertentu terhadap jumlah anak yang pernah/sedang sekolah menurut kelompok usia. Adapun kelompok usia yang dimaksud, yaitu kelompok umur 7-12 tahun, 13-15 tahun, dan 16-18 tahun. Pada tahun 2016, APTS untuk kelompok umur 7-12 tahun menunjukkan 0 persen karena kontribusi dari adanya program dana BOS. APTS untuk kelompok umur 13-15 tahun menunjukkan 1,25 persen. APTS kelompok umur 16-18 menunjukkan sangat tinggi, yaitu 32,94 persen (Indikator Kesejahteraan Rakyat Kabupaten Ngawi 2016).

\section{b. Tahun 2017}

Pada tahun 2017, situasi dan kondisi belum menunjukkan perubahan. Sebagian besar penduduk Kabupaten Ngawi dikatakan masih rendah jika dilihat dari pendidikan tertinggi yang ditamatkan. Hanya sekitar 4,21 persen penduduk usia 15 tahun ke atas yang menamatkan pendidikan hingga ke jenjang perguruan tinggi, sebanyak 29,05 persen penduduk usia 15 tahun ke atas menamatkan pendidikan setingkat SD, dan terdapat 24,32 persen yang belum/tidak sekolah atau belum menamatkan SD (Statistik Daerah Kabupaten Ngawi 2018). Pada tahun 2017, rata-rata lama sekolah penduduk Kabupaten Ngawi hanya 6,66 tahun (Statistik Daerah Kabupaten Ngawi 2018).

Berdasarkan angka partisipasi dan angka partisipasi sekolah (APS) di Ngawi menunjukkan kelompok umur pertama yakni 7-12 tahun atau setara dengan usia SD di Kabupaten Ngawi adalah sebanyak 99,61 persen, untuk usia 13-15 tahun sebesar 99,72 persen sedangkan untuk kelompok usia 16-18 tahun persentase penduduk yang bersekolah adalah 80,35 persen, sementara 19,65 persen sisanya tidak bersekolah lagi. Kondisi ini menunjukkan minat maupun kemampuan penduduk Kabupaten Ngawi untuk melanjutkan hingga ke jenjang menengah atas masih perlu ditingkatkan. Selain APS, indikator lain yang sering digunakan adalah APK (Angka Partisipasi Kasar) dan APM (Angka Partisipasi Murni) (Statistik Daerah Kabupaten Ngawi 2018).

Angka melek huruf Kabupaten Ngawi pada tahun 2017 adalah 88,07 persen yang artinya dari setiap 100 orang penduduk Kabupaten Ngawi yang berusia 15 tahun atau lebih sebanyak 88 orang telah mampu membaca dan menulis sedangkan sisanya sekitar 12 orang belum mampu membaca dan menulis atau salah satu diantaranya, mengingat seseorang digolongkan melek huruf jika dapat membaca sekaligus dapat menulis (Statistik Daerah Kabupaten Ngawi 2018). Angka buta huruf pada tahun 2017 sebanyak 7,5 persen (laki-laki) dan 16, 05 persen (perempuan) (Indikator Kesejahteraan Rakyat Kabupaten Ngawi 2017/2018). Persentase penduduk 15 tahun keatas yang buta huruf pada tahun 2017 mengalami penurunan 0,65 persen dari prosentase 2015 (Statistik 
Kesejahteraan Rakyat Kabupaten Ngawi 2016). Pada tahun 2017, angka buta huruf Kabupaten Ngawi pada tahun 2017 mencapai 11,93 bila angka melek melek huruf menunjukkan 88.07 persen.

Tahun 2017, angka putus sekolah (APTS) Program sekolah gratis yang dibiayai dari dana BOS (biaya operasional sekolah) ternyata mampu menekan angka putus sekolah pada kelompok usia 7-12 tahun atau bersesuaian dengan jenjang SD menunjukkan bahwa Angka Putus Sekolah (APTS) untuk kelompok usia tersebut adalah 0 persen baik untuk laki-laki maupun perempuan. APTS untuk kelompok usia 13-15 tahun adalah 0,28 persen, artinya sebanyak 0,28 persen penduduk Kabupaten Ngawi berusia 13-15 tahun yang pernah sekolah sudah tidak bersekolah lagi pada pada tahun 2017. Tidak bersekolah lagi karena telah lulus dari suatu jenjang dan tidak melanjutkan ke jenjang yang lebih tinggi diperhitungkan sebagai putus sekolah. Sedangkan APTS untuk kelompok umur 16-18 tahun sebesar 19,65 persen, hal ini berarti menurun bila dibandingkan Tahun 2016 yang mencapai 32 persen. APTS untuk kelompok umur 19-24 tahun masih sangat tinggi yakni 82,59 persen (Indikator Kesejahteraan Rakyat Kabupaten Ngawi 2017/2018).

\section{c. Tahun 2018}

Pada tahun 2018, pendidikan penduduk Kabupaten Ngawi dikatakan masih berada pada tingkat yang rendah. Hal ini tercermin dari pendidikan tertinggi yang ditamatkan oleh penduduknya dimana hanya sekitar 6,49 persen saja dari penduduk usia 15 tahun ke atas yang berhasil menamatkan pendidikan hingga ke jenjang perguruan tinggi (D1 hingga S3) sementara 27,08 persen penduduk hanya menamatkan SD/sederajat dan 25,10 persen tidak memiliki ijazah SD. Rendahnya tingkat pendidikan penduduk Kabupaten Ngawi yang tercatat juga disebabkan oleh adanya penduduk muda berpendidikan tinggi yang bekerja di luar wilayah Kabupaten Ngawi, sehingga tidak tercatat sebagai penduduk (Statistik Daerah Kabupaten Ngawi 2019).

Angka melek huruf Kabupaten Ngawi pada tahun 2018 adalah 87,93 persen. Hal ini artinya dari setiap 100 orang penduduk Kabupaten Ngawi yang berusia 15 tahun atau lebih sebanyak 87 hingga 88 orang telah mampu membaca dan menulis sedangkan sisanya sekitar 12-13 orang belum mampu membaca dan menulis atau salah satu diantaranya, mengingat seseorang digolongkan ke dalam melek huruf jika dapat membaca sekaligus dapat menulis minimal untuk kata-kata/kalimat sederhana (Statistik Daerah Kabupaten Ngawi 2019). Angka buta huruf Kabupaten Ngawi tahun 2018 mencapai 12,07 persen bila angka melek huruf mencapai 87,93 persen.

Tahun 2018, APS kelompok umur pertama yakni 7-12 tahun atau setara dengan usia SD di Kabupaten Ngawi telah mencapai 100 persen, untuk usia 13-15 tahun sebesar 98,98 persen sedangkan untuk kelompok usia 16-18 tahun persentase penduduk yang bersekolah adalah 76,71 persen, 3,04 persen tidak/belum pernah sekolah, sementara 20,25 persen sisanya tidak bersekolah lagi (Statistik Daerah Kabupaten Ngawi 2019).

APTS untuk kelompok usia 13-15 tahun adalah 0,28 persen, artinya sebanyak 1,02 persen penduduk Kabupaten Ngawi berusia 13-15 tahun yang pernah sekolah sudah tidak bersekolah lagi pada pada tahun 2018. Tidak bersekolah lagi karena telah lulus dari suatu jenjang dan tidak melanjutkan ke jenjang yang lebih tinggi diperhitungkan sebagai putus sekolah. Sedangkan APTS untuk kelompok umur 16-18 tahun sebesar 20,25 persen, hal ini berarti meningkat bila dibandingkan Tahun 2017 yang hanya mencapai kurang dari 20 persen. APTS untuk kelompok umur 19-24 tahun masih sangat tinggi yakni 84,90 persen. Hal ini sejalan dengan indikator angka partisipasi yang telah disajikan sebelumnya yang menunjukkan bahwa minat penduduk Kabupaten Ngawi untuk melanjutkan ke jenjang perguruan tinggi masih sangat kecil. Minat melanjutkan pendidikan ke jenjang yang lebih tinggi dipengaruhi banyak faktor, salah satunya adalah kondisi perekonomian keluarga (Indikator Kesejahteraan Rakyat Kabupaten Ngawi 2018).

\section{d. Hasil Evaluasi Kinerja Pemerintah Kabupaten Ngawi di Sektor Pendidikan}

Kinerja di atas dijadikan sebagai dasar evaluasi untuk menunjukkan sejauhmana capaian sektor pendidikan yang telah dicapai pemerintah Kabupaten Ngawi. Berdasarkan RPJP Daerah 20052025, arah Pembangunan Tahun 2015-2019 yaitu Pengembangan infrastruktur guna menunjang investasi dan perekonomian daerah. Sebagai keberlanjutan pembangunan berdasarkan pelaksanaan dan pencapaian rencana pembangunan jangka menengah tahap kedua yang didasarkan pada 
peningkatan kemajuan dan kualitas serta daya saing sumberdaya manusia dan infrastruktur sehingga masyarakat lebih produktif dan sistem ekonomi perekonomian daerah yang bertumpu pada potensi pertanian, industri dan perdagangan dapat meningkat yang didukung oleh pengelolaan pemanfaatan sumberdaya alam yang berkelanjutan, maka pembangunan tahap ketiga ditujukan untuk lebih mengembangkan pembangunan secara menyeluruh.

Namun, hasil kinerja pemerintah daerah dalam membangun sumber daya manusia yang berkualitas belum menunjukkan hasil yang membanggakan. Lihat hasil evaluasi kinerja pemerintah daerah Kabupaten Ngawi berikut ini.

Tabel 2. Hasil Evaluasi Kinerja Pemerintah Kabupaten Ngawi di Sektor Pendidikan Tahun 2016-2018

\begin{tabular}{lccccc}
\hline \multirow{2}{*}{$\begin{array}{l}\text { Aspek Indikator } \\
\text { Kinerja Daerah }\end{array}$} & $\begin{array}{c}\text { Target Capaian } \\
\text { RPJMD }\end{array}$ & \multicolumn{3}{c}{ Realisasi Capaian } & \multirow{2}{*}{$\begin{array}{c}\text { Hasil Evaluasi } \\
\text { Kinerja }\end{array}$} \\
\cline { 3 - 4 } & Tahun 2015-2019) & $\begin{array}{c}\text { Tahun } \\
\mathbf{2 0 1 6}\end{array}$ & $\begin{array}{c}\text { Tahun } \\
\mathbf{2 0 1 7}\end{array}$ & $\begin{array}{c}\text { Tahun } \\
\mathbf{2 0 1 8}\end{array}$ & Belum Tercapai \\
\hline $\begin{array}{l}\text { Persentase penduduk } \\
\text { di bawah garis } \\
\text { kemiskinan }\end{array}$ & $10 \%$ & $15,27 \%$ & $14,91 \%$ & $14,83 \%$ & Belum Tercapai \\
\hline Angka melek huruf & $99,25 \%$ & $88.92 \%$ & $88.07 \%$ & $87,93 \%$ & Bel \\
\hline $\begin{array}{l}\text { Angka rata-rata lama } \\
\text { sekolah }\end{array}$ & $\begin{array}{c}11 \\
\text { Tahun }\end{array}$ & $\begin{array}{c}6,54 \\
\text { tahun }\end{array}$ & $\begin{array}{c}6,66 \\
\text { tahun }\end{array}$ & $\begin{array}{c}6,88 \\
\text { Tahun }\end{array}$ & Belum Tercapai \\
\hline $\begin{array}{l}\text { Angka Putus Sekolah } \\
\text { (APS) SD/MI }\end{array}$ & $0 \%$ & $0 \%$ & $0 \%$ & $0 \%$ & Tercapai \\
\hline $\begin{array}{l}\text { Angka Putus Sekolah } \\
\text { (APS) SMP (MTs) }\end{array}$ & $0,01 \%$ & $1,25 \%$ & $0,28 \%$ & $1,02 \%$ & Belum Tercapai \\
\hline $\begin{array}{l}\text { Angka Putus Sekolah } \\
\text { (APS) SMA(SMK, }\end{array}$ & $0,01 \%$ & $32,94 \%$ & $19,65 \%$ & $20,25 \%$ & Belum Tercapai \\
MA) & & & & & \\
\hline
\end{tabular}

Sumber: diolah dari data sekunder oleh tim peneliti, 2020.

Berdasarkan hasil evaluasi ini menunjukkan bahwa secara umum target angka kemiskinan yang direncanakan belum tercapai. Dalam dimensi pendidikan, terutama dimensi yang berkontribusi terhadap peningkatan kualitas sumber daya manusia juga menunjukkan banyak yang belum tercapai. Dari 5 indikator yang digunakan untuk dasar penilaian di sektor pendidikan, hanya 1 yang tercapai, yaitu jenjang sekolah dasar mampu menamatkan pendidikan hingga selesai. Sementara, 4 indikator yang lain belum tercapai sesuai dengan target yang telah ditentukan, yaitu (1) Angka melek huruf, (2) Angka rata-rata lama sekolah, (3) Angka Putus Sekolah SMP/Mts, dan (4) Angka Putus Sekolah SMA/SMK.

\section{SIMPULAN}

Pemerintah kabupaten Ngawi perlu memikirkan langkah strategis untuk mendorong penyelenggaraan sektor pendidikan berkualitas untuk mengatasi persoalan kemiskinan, dalam rangka memajukan perekonomian daerah. Pertama, memperbaiki kinerja birokrasi pendidikan. Pemerintah Pusat melaksanakan program-program sosial percepatan pengentasan kemiskinan dengan memberikan Program Indonesia Pintar (PIP), Program Jaminan Kesehatan Nasional (JKN-KIS), Program Keluarga Harapan (PKH), \& Bansos Rastra/Bantuan Pangan Non Tunai. Bantuan ini diberikan untuk memenuhi dan menjamin kebutuhan dasar serta meningkatkan taraf hidup penerima bansos bagi penduduk miskin (Kementerian Komunikasi dan Informatika RI, 2019). Dengan capaian kinerja yang masih banyak belum tercapai, birokrasi pendidikan pemerintah Kebupaten Ngawi perlu berbenah. Sebab, program-program yang didelegasikan dari pemerintah pusat kepada daerah belum optimal direalisasikan. Kedua, pemerintah daerah Kabupaten Ngawi perlu mencari alternatif biaya untuk mengoptimalkan akses pendidikan (beasiswa) bagi siswa-siswi yang berasal dari keluarga kurang mampu. Studi SMERU telah menunjukkan bahwa dengan adanya program pemerintah, sebagian masyarakat dapat keluar dari kemiskinan. Hal ini menunjukkan bahwa telah terjadi perubahan kesejahteraan masyarakat dari miskin menjadi tidak miskin, atau sebaliknya dari tidak miskin menjadi miskin (Isdijoso \& Suryahadi, 2016). Meski berbagai program bantuan dari 
pemerintah pusat diberikan dan didistribusikan, masih tingginya angka putus sekolah yang terjadi mengindikasikan bahwa program tersebut belumlah cukup mengamankan penduduk miskin dalam kerentanan. Ketiga, mengoptimalkan jalur pendidikan non-formal dan pelatihan keterampilan. Pemberdayaan masyarakat melalui pendidikan non-formal akan mampu membekali berbagai keterampilan hidup agar lebih mandiri (Miradj \& Sumarno, 2014; Raharjo dkk., 2016; Tohani, 2011). Langkah ini perlu dan penting dilakukan mempertimbangkan tamatkan pendidikan penduduk didominasi tamatan Sekolah Dasar, Sekolah Menengah Pertama, dan Sekolah Menengah Atas.

\section{DAFTAR PUSTAKA}

Badan Pusat Statistik Kabupaten Ngawi. (2020). Kabupaten Ngawi Dalam Angka 2019. Badan Pusat Statistik Kabupaten

Ngawi. https://ngawikab.bps.go.id/publication/2019/08/16/e0479d509718f6fb0c6a51ce/kabupatenngawi-dalam-angka-2019.html

BPS. (2020). Indeks Pembangunan Manusia. https://www.bps.go.id/subject/26/indekspembangunan-manusia.html

Hafidh, A. A. (2011). Analisis Hubungan Pengeluaran Pendidikan dan Pertumbuhan Ekonomi dengan Menggunakan Pendekatan Kausalitas Granger. Jurnal Ekonomi \& Pendidikan, 8(2). https://doi.org/10.21831/jep.v8i2.791

Huberman, M., \& Miles, M. B. (2002). The qualitative researcher's companion. Sage.

Isdijoso, W., \& Suryahadi, A. (2016). Penetapan Kriteria dan Variabel Pendataan Penduduk Miskin yang Komprehensif dalam Rangka Perlindungan Penduduk Miskin di Kabupaten/Kota (hlm. 25). The SMERU Research Institute. http://www.smeru.or.id/sites/default/files/publication/cbms_criteria_ind.pdf

Jawa Pos. (2019). 45 Persen Warga Ngawi Kategori Miskin, Pengentasan Butuh Peran Lintas Sektoral. https://radarmadiun.jawapos.com/45-persen-warga-ngawi-kategori-miskinpengentasan-butuh-peran-lintas-sektoral/

Kementerian Komunikasi dan Informatika RI. (2019). Kementerian Komunikasi dan Informatika. https://kominfo.go.id/index.php/content/detail/15708/program-bantuan-sosial-untukrakyat/0/artikel_gpr

Kompas. (2019). Maret 2019, Penduduk Miskin Indonesia Turun Jadi 25,14 Juta Orang. https://money.kompas.com/read/2019/07/15/135853726/maret-2019-penduduk-miskinindonesia-turun-jadi-2514-juta-orang

Lugastoro, D. P., \& Ananda, C. F. (2013). Analisis Pengaruh PAD dan Dana Perimbangan Terhadap Indeks Pembangunan Manusia Kabupaten/Kota di Jawa Timur. Jurnal Ilmiah Mahasiswa Fakultas Ekonomi dan Bisnis, 1(2).

Maulana, R., \& Bowo, P. A. (2013). Pengaruh Pertumbuhan Ekonomi, Pendidikan dan Teknologi terhadap IPM Provinsi di Indonesia 2007-2011. JEJAK: Jurnal Ekonomi dan Kebijakan, 6(2).

Miradj, S., \& Sumarno, S. (2014). Pemberdayaan masyarakat miskin, melalui proses pendidikan nonformal, upaya meningkatkan kesejahteraan sosial di Kabupaten Halmahera Barat. JPPM (Jurnal Pendidikan dan Pemberdayaan Masyarakat), 1(1), 101-112.

Mirza, D. S. (2012). Pengaruh Kemiskinan, Pertumbuhan Ekonomi, Dan Belanja Modal Terhadap Indeks Pembangunan Manusia Di Jawa Tengah Tahun 2006-2009. Economics Development Analysis Journal, 1(2), Article 2. https://doi.org/10.15294/edaj.v1i2.474

Novita Dewi, Yusbar Yusuf, \& Rita Yani Iyan. (2017). Pengaruh Kemiskinan dan Pertumbuhan Ekonomi terhadap Indeks Pembangunan Manusia di Provinsi Riau. Jurnal Online Mahasiswa Fakultas Ekonomi Universitas Riau, 4(1), 870-882. 
Nugroho, S. (2016). Pengaruh Pendidikan Terhadap Pertumbuhan Ekonomi. Media Ekonomi dan Manajemen, 29(2).

Raharjo, T. J., Suminar, T., \& Muarifuddin, M. (2016). Peran pusat kegiatan belajar masyarakat dalam menanggulangi kemiskinan melalui pendidikan nonformal di Jawa Tengah. Journal of Nonformal Education, 2(1).

Suara Indonesia. (2020). Ditengah Pandemi Covid-19, Musrenbangkab Ngawi Sukses di Gelar Via Online. https://www.suaraindonesia.co.id/read/15244/20200407/222016/post-style-2.html

Sumargo, B., \& Simanjuntak, N. M. M. (2019). Deprivasi Utama Kemiskinan Multidimensi Antarprovinsi di Indonesia. Jurnal Ekonomi dan Pembangunan Indonesia, 19(2), 160-172. https://doi.org/10.21002/jepi.v19i2.793

Suryawati, C. (2005). Memahami Kemiskinan Secara Multidimensional. Jurnal Manajemen Pelayanan Kesehatan, 8(03), 121-129.

Tohani, E. (2011). Pendidikan nonformal dan pengurangan kemiskinan di pedesaan. Walisongo: Jurnal Penelitian Sosial Keagamaan, 19(2), 385-398.

Ustama, D. D. (2009). Peranan Pendidikan Dalam Pengentasan Kemiskinan. "Dialogue" JIAKP, $6(1), 12$.

Zed, M. (2004). Metode Peneletian Kepustakaan. Yayasan Obor Indonesia.

\section{Sumber Data (Sekunder)}

Dokumen RPJP Kabupaten Ngawi 2005-2025.

Indikator Kesejahteraan Rakyat Kabupaten Ngawi 2016

Indikator Kesejahteraan Rakyat Kabupaten Ngawi 2017

Indikator Kesejahteraan Rakyat Kabupaten Ngawi 2018

Kabupaten Ngawi Dalam Angka 2016

Kabupaten Ngawi Dalam Angka 2017

Kabupaten Ngawi Dalam Angka 2018

Kabupaten Ngawi Dalam Angka 2019

Statistik Daerah Kabupaten Ngawi 2017

Statistik Daerah Kabupaten Ngawi 2018

Statistik Daerah Kabupaten Ngawi 2019

Statistik Kesejahteraan Rakyat Ngawi 2016

Statistik Kesejahteraan Rakyat Ngawi 2017

Statistik Kesejahteraan Rakyat Ngawi 2018 